\title{
'Clan' and 'Family': Transformations of Sociality among the Wampar, Papua New Guinea
}

\author{
Bettina Beer (D)
}

Citation: Beer, B. 'Clan' and 'Family': Transformations of Sociality among the Wampar, Papua New Guinea. Histories 2022, 2, 15-32. https:// doi.org/10.3390/histories2010002

Received: 23 June 2021

Accepted: 2 December 2021

Published: 14 January 2022

Publisher's Note: MDPI stays neutral with regard to jurisdictional claims in published maps and institutional affiliations.

Copyright: (C) 2022 by the author. Licensee MDPI, Basel, Switzerland. This article is an open access article distributed under the terms and conditions of the Creative Commons Attribution (CC BY) license (https:// creativecommons.org/licenses/by/ $4.0 /)$
Department of Social and Cultural Anthropology, University of Lucerne, 6002 Lucerne, Switzerland; Bettina.Beer@unilu.ch

\begin{abstract}
Changes in what anthropologists understand "clan" to refer to, and the social relations that many sociologists think of as constituting a "nuclear family" are at the centre of this article. It is based on ethnography among Wampar speakers in north-eastern Papua New Guinea (PNG). Among the Wampar, different, sometimes conflicting, transitions relevant to the emergence of the family as an accentuated social entity can be observed; yet all are a result of Christianisation and the local effects of capitalism. Nominally patrilineal clans (sagaseg), after a period when they seemed to have a somewhat diminished social significance, are again crucial social units: a result of the government's requirement that statutory Incorporated Land Groups (ILGs) form the sole legal basis of compensation for land use. At the same time, there has been an increasing emphasis on the nuclear family, which, along with the aspiration for modern lifestyles (and their associated consumption patterns) and education for children, has reconfigured the gendered division of labour. Ideals of companionate marriage and values specific to the nuclear family have become much more critical to social practices. In some families, traditional notions of descent have lost importance to such an extent that some young people are no longer aware of their sagaseg membership. Wampar men and women discuss these conflicting tendencies and argue about the different values that ground them. Which argument prevails often depends on the specific position of the person confronting them.
\end{abstract}

Keywords: middle-classes; Papua New Guinea; transformation of the family; clan; nuclear family

\section{Introduction}

In the late afternoon when the sun is lower, one frequently meets couples coming back from a long, hot day in one of their subsistence gardens near Gabsongkeg, a village in the Markham Valley where I have performed fieldwork since 1997. The woman's head strains against the weight of a netbag full of garden products, which she will prepare with other female relatives for the evening meal. Often, she carries a second netbag in which a baby sleeps. Her husband walks in front or behind her, perhaps pushing a bike with one or two toddlers on it, while other children run around the couple. Similar scenes occur on most days; they provide a snapshot of routines specific to a stage in the life cycle of a young couple who have children. It is, in fact, one of the few occasions on which one can see a nuclear family together, for, once in their households, each family member socializes with relatives, neighbours of his or her own age and gender, or both.

'Wampar' refers to a language group of some fifteen thousand persons occupying a very extensive area of the middle Markham Valley in Morobe Province. It is located along PNG's busiest highway and close to the city of Lae, the second biggest town in PNG, as well as a gold and silver mine and a proposed second-and even bigger-mine in the Markham Valley (see Figure 1) ${ }^{1}$. Land remains central to ways of life in PNG, even while relations to land are changing under the influence of the state's uniform systems of laws [1,2]. The majority of families, called 'smallholders' or 'customary landowners', still depend on land for food production and access to timber and other vital resources. Today, they also hope for income from rents, leases, and royalties or compensation for land use 
by international corporations. More and more non-Wampar people are settling, working on and with Wampar land. Patronage-like relations emerge, as do illegal settlements, increased theft of garden products and greater pressure on land as an important resource. The Wampar language, before the introduction of Tok Pisin (PNG's widespread lingua franca), had no term that might be translated as 'nuclear family' [3]. Nevertheless, they recognized, acknowledged and spoke about the unit that today is referred to as a femili or, if English rather than Tok Pisin is being used, a family.

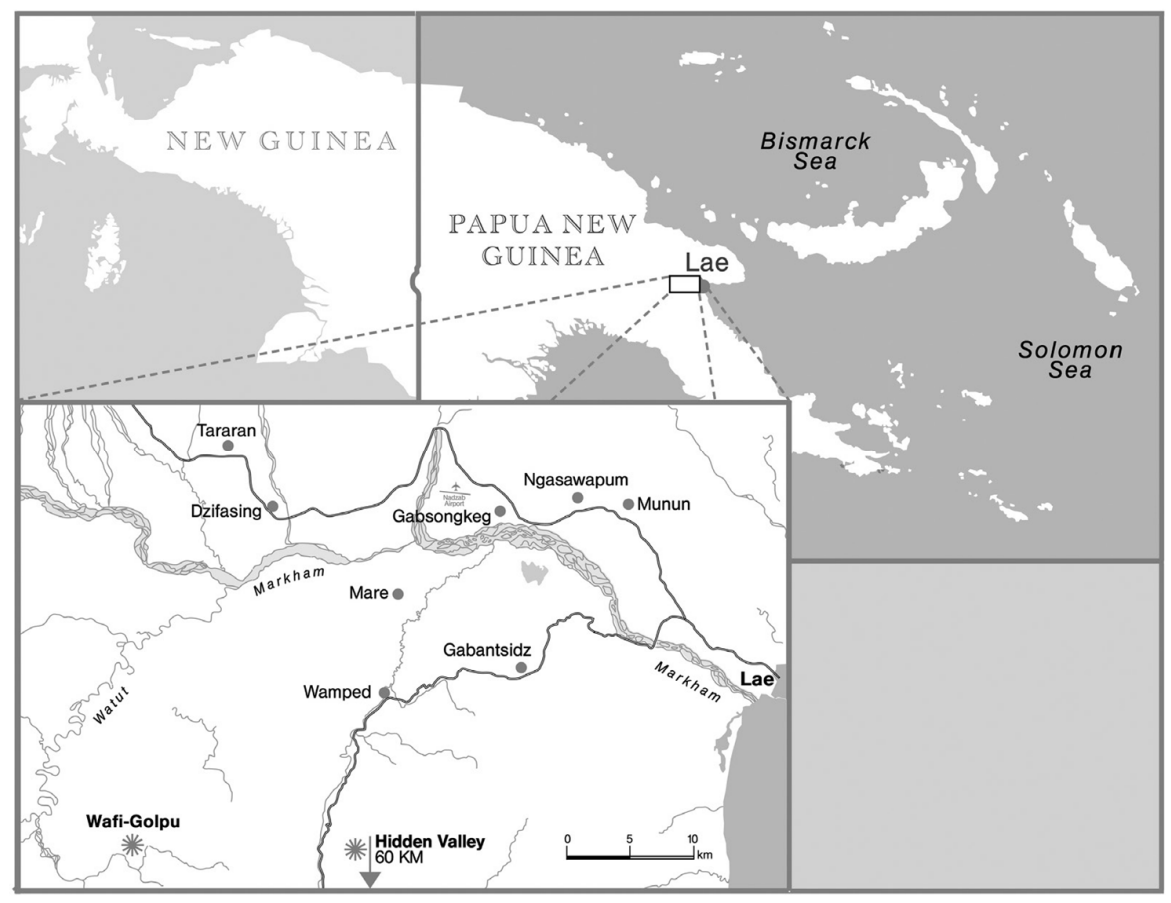

Figure 1. Localization of Wampar area and map of the Markham Valley showing Wampar villages and mining sites (map Heiner Schnoor).

The term 'family' has entered European languages and their domestic terminologies quite late, as Jon Mathieu [4] shows in his comprehensive description of the term's history in six European languages from 16th to 20th century. Initially, people within a household, or kindred addressed each other with names or appropriate kin terms, and talk about their position in social units became subject of discourses in religious, legal, and political contexts. Who was included or excluded has changed in Europe over time, which makes the notion of 'the western family' rather problematic. 'Family' is a polysemic term and has been used in many combinations (e.g., nuclear, extended, stem, modern, bourgeois, western, or conjugal family) [4]. When I write about specific local usages I write 'family' in inverted commas or use the Tok Pisin or Wampar vocabulary. When I use family as an etic term I do so in a general sense, understanding it as the smallest recognized or marked social unit based on a bundle of social relations organised around domestic provisioning and the raising of the household's children when necessary. I use the appropriate composite terms (conjugal, stem, or extended family).

The scene described above, which looked to me as the peaceful culmination of the day a young nuclear family had spent in their gardens, looked to the early German Lutheran missionaries from Neuendettelsau (Bavaria) as a sign of the 'sad conditions of marriage' among the Wampar:

'Marital relations among the Laewomba [old ethnonym for 'Wampar', BB] are the saddest imaginable. The Laewomba does not know love or affection in the Christian sense. The woman, because she has to be bought, is only a commodity to him, the Laewomba does not know a cordial affection in the Christian sense. [] Husband and wife never eat together [ ... ] When husband and wife go to 
the field, the wife always walks a few steps behind him, so that strangers have the impression, that they are not at all related.' (Stürzenhofecker in [5] (p. 99), translation BB. $)^{2}$

Neuendettelsau Lutherans aimed at improving marriage and family life through their religious teachings at church, through education at the early bible schools and in daily activities. After they arrived at the beginning of the 20th century, they ended infanticide, tried to stop polygyny, taught Yabim (a language of another Lutheran region) as their preferred lingua franca, established a bible school then an elementary school, and educated the first Wampar evangelists. Their impact on the re-negotiation of gender relations was quite substantial [2]. The Lutherans built churches in each Wampar village, demanded attendance at Sunday services, appointed church elders (ngaeng tsaru), and established regular Sunday schools for children as well as communal meetings on Fridays (dzob a gomrenan) to discuss current problems of the community (marriage problems were common).

The vignette which opened this article shows that Wampar do gather in 'family' formations, however, this tended to be limited to specific occasions and activities (e.g., a joint visit to a garden) and to a certain stage in the life cycle. It would be wrong to say 'Wampar didn't know or have nuclear families' but it is obvious that the family was not the social unit of permanent and pervasive importance as it is in other parts of the world in segments of society strongly influenced by middle class ideals. Yet, today the nuclear family is becoming more and more important, while the sagaseg, patrilineal 'clans', also gain a new significance. This article will show how the family and patrilineal ideologies arise from the same postcolonial context of Christianisation, the spread of education, consumerism, and urbanisation, and nearby large-scale capitalist projects ${ }^{3}$. This article aims at explicating conditions of the transformation of the family with connection to processes relating to larger social units.

I will give an empirically focused overview of these processes. For, even if the world always moves small-scale societies in definite directions, it does not always make them follow the same route. The exact nature of the journey people such as the Wampar make is significant to our discipline.

\section{Social Science Research on the Rise of the Family}

The notion of the family is grounded in the necessity to share the huge effort required to raise a human baby to independence [6]; it has very different forms and characteristics, depending on a range of factors, all of which are under transformative pressure through the globalisation of certain aspects and characteristics of family life associated with late capitalism. In anthropology there are a few areas in which the export of the concept of the family as a primary social unit is investigated, usually as part of broader research interests. Anthropologists have addressed these transformations in research on migration and transnational families, on adoption and fosterage, and on the rise of romantic love and companionate marriage $[7,8]$. Sometimes the neglect of research of the unit is based on the critique of using etic concepts, although the emic use of these (modified) terms has become common. In this article, I try to show that the careful separation of etic and emic perspectives (although boundaries are often fuzzy) is helpful to analyse and understand local usages.

\subsection{Emerging Middle Classes}

The growing middle class in the global south and values attached to its development have become an important area of anthropological interest and research [9-11]. Most of this work underlines the importance of education and 'modern family life' to 'being middle class'. As Carola Lentz [11] emphasises, the terms 'middle class' and 'elite' are emic as well as etic terms, and changes in their everyday and social science use influence both. In the same manner as the African ethnographies, studies on Papua New Guinea initially focused on 'elites' e.g. [12,13], and 'middle classes' have been researched only since the late 1990s [14-18], although some (local) voices question its existence. Gewertz and 
Errington [17] report in their only book-length study of PNG class distinctions that middle class values in Wewak (a small town in PNG) are shaped by global processes and claim that the local middle class is differentiated from the 'grass-roots' mainly through consumption patterns. They claim that attached values aimed at self-interested production and consumption are radically opposed to investments in social relations in village based socialities. Cox and Macintyre [16] show how Neo-Pentecostal Christianity affects ideas of companionate marriage, gender and middle class values. This corresponds with ethnographies of African middle classes.

African middle class imaginaries are connected to romantic love, family planning, specific ways of parenting, and privileging the nuclear over the extended family, but most studies on middle classes in Africa also show ... 'that contrary to modernist aspirations towards the nuclear family, three-generation households and multiple material as well as symbolic obligations towards extended kin networks are the rule rather than the exception, even among upper-middle-class groups.' [11] (p. 31). Polygamy and bride price payments continue to exist (ibid.) as they do in Papua New Guinea.

Some ethnographies are part of the field of research on the connections between middle class aspirations, migration and labour beset by the conflicts and challenges of 'scattered families' [19-22]. Catie Coe, for example, describes how middle-class Ghanaian transnational migrants and their kin cope with the paradoxical situation of emerging middle class family ideals while, at the same time, solving problems of 'distributed parenting' in the context of migration and transnationalism. She shows how the job market and the legal system in the U.S., and the need to care for aging parents and children, together create new 'repertoires of family life' among migrants. Heike Drotbohm [23,24] deals Cape Verdean households in a similar context, analysing translocal motherhood and longdistance 'intimacies'. Unfortunately, she treats the household as the unit relevant to her argument about transnational relations (based on a 'renewed' anthropology of kinship). The problem here is that households and relations of cohabitation can be dissolved while familial relations, as categorical relations, continue to exist and could be activated again despite circumstances that render interactions impossible. In this respect kin relations precisely contrast with relations grounded in cohabitation and intimacy.

\subsection{Adoption, Fosterage and the Circulation of Children}

A second field of research in which the growing hegemony of the nuclear family has been discussed is adoption, fosterage and the circulation of children [25-28]. Caroline Archambault [26] shows how tendencies to 'nuclearize' the family challenge practices of fosterage among the Maasai of southern Kenya, where child circulation had been widespread. She shows in ten case studies the perspectives and experiences of adopted children and their families, and examines the processes by which parents and children attempt to 'recreate kinship.' Emphasis on children's experiences demonstrate their active role in, and sometimes resistance to, new ideals of family and residential fixity, such as the assumption that 'modern' family life should be small, settled, and nuclear. These ideas of the modern family are embedded in the school syllabus and textbooks, to which children are exposed. Still, attempts to implement these ideas are not very successful and create a gap between lived experiences and efforts to 'modernize' the family:

"Adoption is widespread in Enkop [her fieldsite, a Maasai village] despite pressures of family nuclearization arising from land tenure transformations, expansion of education and Christianity, and various developmental initiatives aimed at modernizing family life. Children continue to circulate within and across households and the Maasai uphold proudly ideological notions that children belong to no single person or place. However, and unlike many other studies on child circulation in sub-Saharan Africa, pervasive sedentarizing discourses and pressures seem to have pushed parents in Enkop towards a more unitary concept of parenthood and sedentary concept of home." [26] (p. 238) 
Leinaweaver, Marre and Frekko [28] also report on the connection between adoption and the production of 'modern families' in the official screening process of transnational adoption in Spain. They describe the co-production of the home and the family as a process of 'homework', in which the gendered and class specific norms (especially in respect to proper houses and homes) taken for granted in state discourses are taken up by families.

\subsection{Romantic Love and Companionate Marriage}

The rise of the idea of companionate marriage and love [8] is a third area in which the concept of the family has been implicated. Changes in ideals of courtship and romantic love contribute to visions of the family by promoting the importance of specific aspects of their internal relations. Such ideals are influential in contexts where missionaries have had a big impact, for the heteronormative couple is taken for granted in traditional Christian models of the family. In the realm of consumption, sexual attractiveness and ideas of romantic love underwrite the appeal of fashion items and other commodities [29,30], including costly leisure-time activities. Parental and romantic love are idealised on special occasions (Mother's, Father's and Valentine's Days, birthdays, and Christmas). An emphasis on these relationships, which are central to notions of the family and connected to both production and reproduction, is integral to the advent of consumerism in different parts of the world. In the last two decades, for example, elaborate children's birthday parties have been introduced among Wampar. They do not (yet) include personalized gift giving but they do include the consumption and distributions of partly traditional, but mostly modern food and birthday cakes bought in town. These patterns of conspicuous consumption also contribute to the view that the family is a specific and central unit in social life.

\subsection{Sociology of the Family}

Since the demise of Parsons' 'functional fit theory' [31] of the nuclear family-its functions change to fit society's changing needs-sociologists have struggled to describe and explain family change. Lately, Arland Thornton's publications [32,33]-influenced by the historical demographer Peter Laslett-have come closest to a systematic approach to understanding the rise of a (Euro-American) 'family ideology', its 'export' and resulting transformations of familial relations to other parts of the world. Thornton [32] criticized the misinterpretation of the history of the family in Europe, which was mainly based on a Western evolutionary paradigm from the 18th and 19th century and a modern American developmental idealism. This has influenced perspectives on family policies and family planning, health, education, and human rights [33]. Developmental idealism and notions of healthy modern families have been actively spread by social science, social workers, NGOs, and organizations such as the WHO.

Thornton stimulated important comparative sociological research on the transformation of relations making up 'the family', although his earlier work was based on a dichotomy of 'the west and the rest' (mostly meaning the U.S. versus 'third world' or non-Euro-American), which has proved to be problematic for understanding the entanglements of local processes in transcultural encounters. In his line of argument, populations addressed by developmental policies, governmentality or capitalism seem to be passive recipients. Resistance, re-interpretation and the creation of syncretistic or 'hybrid' forms have little space. However, Thornton's Reading History Sideways [32] has addressed many important aspects of family change in cross-cultural perspective and has persuasively argued for the significance of diverse ways of life as contexts of demographic family change.

David H. Morgan [34-36] emphasises family practices and claims to go beyond established understandings of the family as an integrated system, pattern or configuration [37], with a 'family structure' and 'roles' [38], all of which are caught up in problematic functionalist approaches which he wants to avoid. Building on, but leaving behind, Morgan's work, a more recent trend in sociology focuses on intimate relations or 'intimacies' across cultures. Lynn Jamieson [39-41] suggested a shift from family/familial relations to intimacy/intimate relations to overcome methodological nationalism and Euro-North-American ethnocen- 
trism; she writes 'The cultural celebration and use of the term 'intimacy' is not universal, but practices of intimacy are present in all cultures.' This makes understanding close 'intimate' social relations in a cross-cultural perspective even less clear and specific than e.g., mother-child, husband-wife or sibling relations. Thus, the notion of 'intimacy'-as a replacement for sentiments as part of specific kin relations- is not very helpful to see how the hegemonic concept of the family is reconciled in cases of spatial separation, with contradicting migration experiences, necessities, and constraints of long-distance family relations (see Drotbohm [23,24], or for the Philippines also Parreñas [21,22]). 'Intimacy' is an even fuzzier abstraction than kin and 'family', involving emotions which are difficult to operationalize in comparative empirical research. The notion of intimacy is not offering much common ground for understanding what we are talking about when we try to describe and explain the transformation of close social relations.

\section{Circulating Concepts of 'Clan' and 'Family'}

Anthropologists trying to understand the unfamiliar sociality of Melanesian ways of life first applied ideas and concepts forged in other parts of the world. Thus, for example, one of the first misunderstandings in the anthropology of kinship in Papua New Guinea was based on the transfer of models developed from research in Africa to the-only much later accessible-New Guinea highlands. John A. Barnes [42] described in his now famous article 'African Models in the New Guinea Highlands' the shortcomings of the transferred notion of patrilineal 'clan' to New Guinea, where, for example, numerous non-agnates were included ${ }^{4}$. Status differences within the clan between agnates and non-agnates were often absent and men had some choice about the group to which they wanted to affiliate themselves. Furthermore, relations created by marriage were emphasised in ways that made boundaries between local groups much fuzzier than expected and genealogical relations between clan-mates less clear than the models had indicated; names of apical ancestors were sometimes forgotten and ancestors were not the focus of cults that gathered agnates from different co-ordinate segments of the clan. In short, the New Guinea clan appeared less the skeleton that gave form to social organisation than a dynamic yet central aspect of broader social processes.

Despite Barnes' critique [42], the model of the agnatic clan as a fundamental social unit became widespread and acquired a life of its own. Today, 'clan' (Tok Pisin klen) is integrated into the vocabulary of local languages and its use is widespread in government policies. In the frequent land conflicts around large-scale capitalist projects the (patrilineal) clan gained new importance in negotiations about the inclusion or exclusion of in-married partners and their relatives, and about the grounding of rights in gender [43-47].

The family is central to the reproduction of any social unit whatsoever because it implicates statistical and moral norms central to the having and raising of children. This perspective focuses on universal problems of the units of social reproduction and deviates from current developments in 'New Kinship Studies': Since the work of David Schneider [48], and those who have taken up his ideas, such as Marilyn Strathern (e.g., [49]) and Janet Carsten [50], a deep suspicion has developed towards the ethnocentric descriptions of social relations that, it is argued, anthropological work on kinship has promoted. Some anthropologists see deep differences between persons conceived as 'dividuals' (in Melanesia) and those conceived as individuals in 'the West' $[51]^{5}$, or between those societies that stress the 'doing' or 'making' of kinship, rather than its procreative nature [52,53], or a combination thereof. From the perspective used in this paper, these dichotomies and developments in the anthropology of kinship obstruct a more productive view on current transformations of kin relations and the basic social units they form ${ }^{6}$.

Although anthropologists have been more suspicious of the concept of 'family' than of 'kinship', many ethnographers have used it in descriptions of their field sites. Today, partly because of its circulation in Christian teachings connected to normative assumptions about modern notions of the family, the term 'family' has become ubiquitous. The 'modern family' is also connected to a desire for development and its associated discourses on the 
improvement of education, health, and local economy. Thus, ideas of the 'patrilineal clan' as an important organizing unit, and ideas about the 'family' as the most important unit of social reproduction, have been spreading in even remote areas such as Melanesia; these present the family as a bundle of first degree kin relations developing from a 'companionate marriage', and as inherently imbued with values about good parenting and the domestic arrangements it necessitates.

This article concerns the growing emphasis on the nuclear family among the Wampar, in the context of the simultaneous resurgence of the importance of 'patrilineal clans', as linked aspects of recent social change. While globalization has involved the spread of normative ideas and practices concerning the nuclear 'conjugal family', such that it has become a hegemonic concept, and even where it is contested by recent developments (same sex families, for example), that contestation acts to stabilize it as a fundamental unit (cf Godelier [54] in his introduction), the specifics of Wampar history inflect its local encompassment.

\section{Inclusion and Exclusion in 'New' Social Entities: 'Patrilineal Clans' (sagaseg)}

Wampar-at the moment of colonial intrusion-occupied a massive area of the fertile flats of the Markham Valley, a fact that continues to influence their situation today. Since the earliest missionary ethnographers, the main landholding group among the Wampar has been described as the sagaseg ${ }^{7}$, a large, encompassing group membership, which was inherited from one's father. The significance of the sagaseg has declined for some time, sometimes in favour of the smaller units, referred to as mpan (lineage, extended family), and sometimes the nuclear family as the most important reference point. These changes were explicable in terms of the transformation of land use, marriage and kinship patterns, and settlement practices that resulted from colonisation, Christianisation, and the engagement with market forces ${ }^{8}$. With the advent of mining, however, the sagaseg and the mpan are once more crucial to social life, mostly because of a legal context that demands the formation of state-recognised benefits-receiving corporations (Incorporated Land Groups, short ILGs), which were established by the PNG government in 1974, just before independence [55].

In fact, the commercial use of land has led Wampar to employ more strictly a notion of usufructuary rights (the right to use without altering or impairing the land). A specific person (and her or his nuclear family) is now often granted the right to use land only for specific purposes, depending on the person's relation to the sagaseg. The right to use the land in this way can be revoked. A non-Wampar husband of a Wampar woman, for example, has the right to use land for a food garden for daily needs but not for a cacao garden or for direct commercial purposes. If he ignores this restriction, his house or shop might be burnt down. These use-rights are negotiated and renegotiated within the sagaseg and between its component sub-groups in ways that depend upon a much broader range of social relations than are usual in commercial contexts.

If patrilineal clans are understood as the 'traditional' landowners, which conforms to the views of many male politicians and businessmen, women, in a context of increasing interethnic marriages, are excluded from positions of influence, because they may not pass on membership to their children, despite all women's rights initiatives and their formal inclusion in ILGs under the 'Land Registration (Amendment) Act', which requires that on each committee there should be 'two female persons elected by the members of the incorporated land group' [56]. So, while Wampar women are listed as members of ILGs (through their links with their father's sagaseg), they are in most cases excluded from negotiations and decisions about land use. In-married non-Wampar family members are also excluded in most cases. As Anderson [1] (p. 13) summarises, 'Those with secondary rights to land, such as women in patrilineal systems, may be subordinated but not excluded. Indeed, new forms of land use which demand more clearly defined ownership threaten greater damage to the secondary title holders.'

In general, relations to land are influenced by the institutions of PNG's weak state, especially its legal regime, which is overburdened with lengthy and expensive court-battles 
about land. The general result is uncertainty, which does not, nevertheless, prevent wellresourced international companies from achieving their goals. This legal vacuum also offers individuals with greater familiarity with government procedures the chance to take advantage of their kin. In the absence of a clear legal regime of dispute resolution, recognition, and enforcement of decisions, in the grey zone between 'custom' and 'law', certain people can play both sides. Local understandings are swamped or rendered unreliable by conflicting information and the indeterminacy of official rulings. National and international governments, as well as non-government organizations, advocate gender equality, but powerful forces tend to lead to the exclusion of women from land rights and the benefits that accrue from leasing or selling land. Macintyre [57] (p. 218) wrote twenty years ago, 'Papua New Guinean men ... have become enthusiastic litigants and there is ample evidence of their desire to legitimate the subjugation of women by extending customary law into other areas.' As Wampar sagaseg enter the state-controlled legal arena, some well-placed families or (predominantly male) individuals have become involved in the many court cases that have the effect of confusing or disenfranchising less privileged members.

The underlying cause of these developments, which directly affect Wampar families and gender relations, is the increasing commercial value of land understood to be 'owned' by patrilineal sagaseg. By 2000, the demand for land in Gabsongkeg had dramatically increased because of its location close to the Highlands Highway, actual and proposed mining sites, the growing city of Lae, and Nadzab Airport. Over recent years, rumours that Morobe Mining Joint Venture's headquarters would be built near Nadzab, that a new bridge would be constructed over the Markham near Dzifasing, and that the Highlands Highway would be widened to four lanes by 2016 has fuelled interest in Wampar land still further.

The PNG state's current requirement that 'incorporated land groups' (ILGs) be established within a population as the basis for interaction with large-scale projects, and the leasing or selling of land, has reshaped sociality in Melanesia in various ways [43,58,59]. The state's interest in providing a legal framework conducive to development has not only commoditised land, but also led to the formation of new collective actors, who must employ the notion of 'customary landowner' to secure legal rights over land; it has also stimulated new processes of inclusion and exclusion framed in terms of kinship, gender and ethnicity (cf. Mowbray [60]). This process is extended with uncertain consequences by the possibility of founding 'Development Associations'.

Differential access to fertile land as the most valuable means of production for Wampar families has always been an aspect of local political processes, but it now provides the basis for new inequalities between families. Access to land does not necessarily guarantee upward mobility, but the inaccessibility of a family's land makes the establishment of any income from it, through leases, or cash crops, very difficult, or even impossible. Land was and is an increasingly valuable commercial asset that has become a much-contested resource in the Markham Valley. Wampar currently occupying the land now have relations to, and ways of using, this resource that are in marked contrast to traditional relations. The state is imposing 'land rights' and a development ideology that directly and indirectly stimulate ongoing change to the content of social relations.

Government initiatives have transformed 'smallholders' (villagers holding land under local traditions, [61]) into 'customary landowners' (the state's category) organised in Incorporated Land Groups (ILGs). Transformations of land relations are enshrined, for example, in the context of government endorsed 'development agreements' [58] (p. 6). In these processes, the PNG government imposes its own version of 'customary law' [58,61], which has wider consequences for social relations (within and between families), patterns of social inequality and gender relations, all of which tend to reconfigure the fundamentals of sociality as compared to an earlier era (as described by Fischer [62] and the author [2,46]). In 'customary' systems, whether 'patrilineal' or 'matrilineal', men and women had rights to land, so Wampar women have been never completely excluded from access to land. After its comparatively conspicuous absence, the state is now very much present in the 
daily lives of Wampar, as is required by international economic interests. The government, in seeking, even in the remotest areas of PNG, to regulate land transactions by imposing new definitions of land and its ownership, has ensured a close linkage between land and new, reproducible inequalities. In the days before ILGs, Wampar women could achieve politically and economically powerful positions with respect to sagaseg land. Today, the administrative structures of ILGs exclude women from many decisions and sometimes from the benefits (e.g., money earned can be spent before sisters have the chance to know about and claim it) and some men now argue it is their 'customary right' to exclude them.

Depending on the amount of land a sagaseg can claim, the number of brothers and sisters who count as members, and their socio-economic situations, many different outcomes for individual families are possible: from landlessness, because of an unfortunate starting position, imprudent land-sales, or both, to a situation in which access to garden land is secure along with a steady cash income from rent or leases. The couple has become a much more important dyad than before around which work, cash income, education and food supply within the nuclear family is organised. Thus, changes in gender relations are fundamental for the transformation of the family.

Discussions, negotiations, and informal and institutionalized meetings concerning land conflicts are usually not open to women, although state laws demand their representation and participation [56]. There are two strands of exclusion which are clearly linked: one concerns the benefits-how women and certain households are less likely to receive money, and when they do, they are more likely to receive less. The second is the process of institutionalization of ILGs and landowner associations that 'inflates' existing male power and leaves women and certain men playing a minor role in erecting the local legal architecture of these entities. Furthermore, the potential positive feedback loops set up by these processes intensify existing gender inequalities. Asymmetries of power in gender relations do matter to the conjugal family and therefore controversies about land issues impact on family relations: Several Wampar women claim that under new legislation regarding gender equality, the idea of patrilineal clans as customary landowners cannot be defended as they operate in conflict with anti-discrimination laws. According to some female voices, the inheritance of land rights should be understood today as bilateral, also because leasing and selling of land is a 'modern' and not a customary transaction to which so called 'customary rules' will not apply.

A contemporary 'landowner' who leases his portion of sagaseg land to migrants, typically uses part of his income for his nuclear family, while much of it is used for his own needs for drink, gambling, and travel to exotic destinations. As in other parts of PNG, the distribution of benefits under current circumstance becomes increasingly exclusive, in ways that depend upon the accidents of hereditary kin connection, gender and age at the time that income sources become available [59,63-65]. How land negotiations and new land titles, leases, and sales affect the family and the position of men and women in different social contexts is one of the arenas of conflict-as in the case of the new biomass project [66]. The wider socioeconomic conditions influence gender relations and the emerging social inequalities within and between families, men and women, old and young. The possibility of sending children to school is an important site of articulation between the nuclear family, inequalities and relations between the generations; questions of school and university fees, who should be encouraged, and who provides appropriate role models for the young all influence the life-chances of children.

\section{The Rise of the Nuclear Family among Wampar}

\subsection{Christianisation}

Early Lutheran missionaries from Neuendettelsau collected Wampar stories and myths, worked on the language and produced manuscripts about different aspects of the Wampar way of life. A missionary, Karl Panzer, according to the reports, was a 'difficult' personality; he permanently complained to colleagues and the administration about his situation. He arrived alone; the mission only sent him a wife (supposedly he had never met her before) 
to live with him at the station after local people complained about his behaviour towards his female helpers. They had two children, but the marriage failed. Panzer finally lived with a woman from the Wampar village, Munun, and their son, near the Watut. Panzer was deported by the Neuendettelsau mission and died in a mental home in Bavaria. His son stayed and died in PNG. Panzer was neither a role model for Christian marriages nor for a pastoral household [67] (pp. 105-113).

In contrast, the carpenter, Stürzenhofecker, and his wife provided just such a 'model household'. He educated evangelists who were sent to bring the 'good news' to surrounding groups, while his wife introduced Wampar girls to the ways of a good Christian housewife. Stürzenhofecker's daughter remembers: 'My mother always had several girls in the house to teach them sewing and hygiene (see Figure 2). After a few years, they went back to their villages and passed on to other women what they had learned. Some of the men who became teachers or evangelists married such girls.' [68] (p. 15, translation BB.) Missionaries introduced ideas of the nuclear family, the conduct in a proper Christian marriage and household, and dress codes (introducing for example the meri blaus ${ }^{9}$ ), as they did in other regions of PNG [69]. However, one should be careful not to link missionary presence and changes in domesticity as direct causal chains [70] (p. 11) and not to be simplistic about the consequences of missionaries' interventions that led to conditions facilitating further changes: Wampar and missionary lives were linked in many ways through the much broader colonial context.

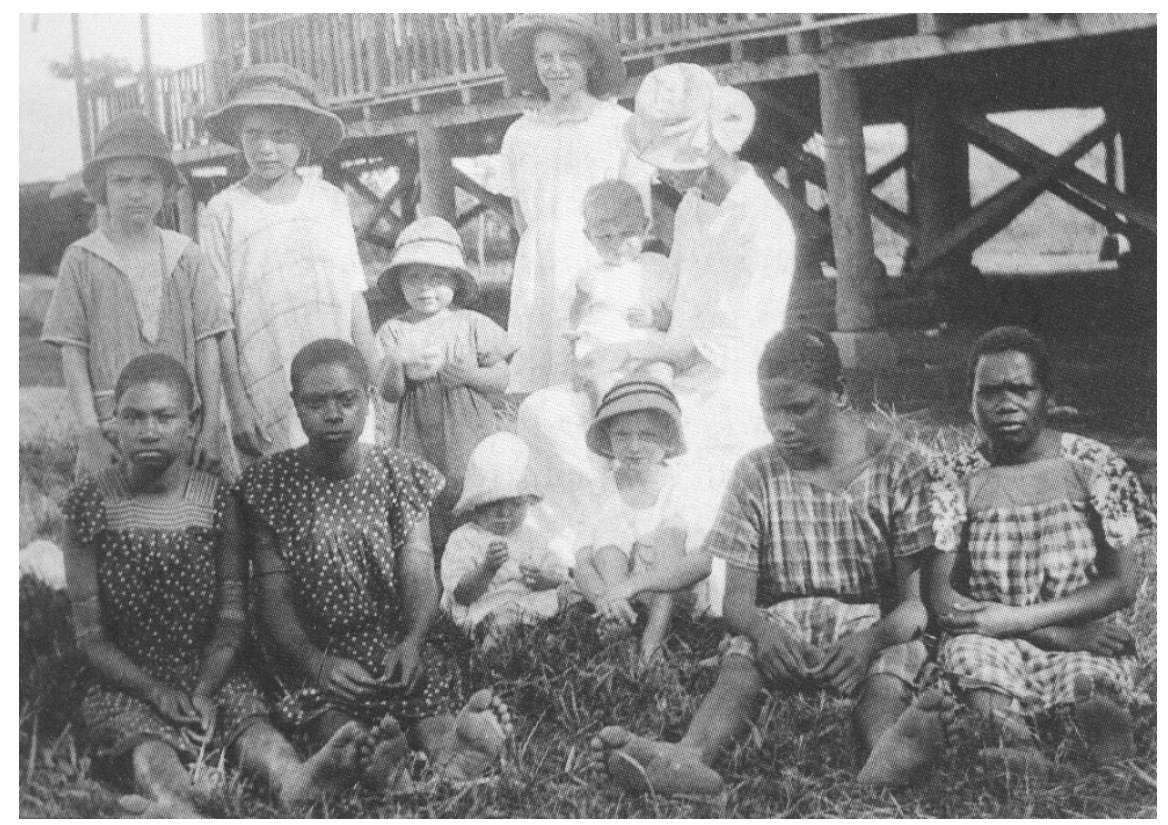

Figure 2. Maria Stürzenhofecker with her seven children and her domestic helpers Senseren, Mampan, Ofenzia and Bonka [68] (p. 15) (photo by the author).

\subsection{Marriage, Gender Relations and Domesticity}

Holly Wardlow's [71-73] astute analyses of Huli sociality describe the paradoxical effects and unintended consequences of some Huli's striving for, and struggles with, a Christian identity and its normative conjugal patterns. Christianisation led many Huli to the view that couples should live in a monogamous marriage and that a husband should live with his wife and children in one house, whereas men had formerly led highly mobile lives (and some still do). Wardlow also describes how fundamental ideas about pollution impact on gendered behaviours and domestic arrangements. For many Huli men, cohabiting with a wife increases the dangers of excessive sexual contact and the 'corporeal hazards of excessive spousal proximity'. Furthermore, men may worry that women would come to know them too well, gaining knowledge that they might use in 
humiliating public conflicts. These difficulties can lead to men's tendency to spend more time in men-only drinking places and to seek prostitutes as a way of avoiding domestic dangers. These changes have also led to an increase in the frequency of domestic violence and in the seriousness of fights, which now happen in the privacy of the domestic sphere, where outsiders have less chance to mediate in the conflict and moderate its course. Thus, among the Huli, Wardlow suggests, the promoted ideal of the 'peaceful Christian home' is not a solution to the problem of domestic violence, but part of it.

Among Wampar, conjugal cohabitation has long been a normal feature of the unspectacular beginning of a marriage (except in cases of elopement): the young woman usually moves into the household of her husband's parents. After the couple have been living together for a while, people begin speaking of them as husband and wife. After the birth of the first or second child, they might build a house of their own.

However, there were two stages in life when gendered separation was required: males above the age of about fourteen lived together in a separate bachelor's house (hausboi), while a woman, after giving birth to a child, went back to stay with her parents and brothers for several months (and when this was not possible for some reason, she moved to other relatives or the husband moved back into a bachelor's house).

Bachelor's houses have decreased in number in recent years, as my census data show. Young men tend to stay longer in their parents' house; sometimes, as some parents explained, because it is easier 'to control' them. Other villagers said that this generation of young men are too lazy to build a hausboi, or that they refuse to work together, preferring to drink alcohol to excess and listen to loud music, which leads to more village conflict. My most recent census revealed that several young men work outside the village, or attend boarding schools, returning home only during holidays, which might also contribute to a lack of interest in hausbois.

Formerly, the post-partum taboo on contact between father and child was especially strict after the birth of the first child and usually lasted for nine months. After the second child, the taboo period lasted only four months, while with subsequent births two months of separation were considered sufficient. Wampar thought that the taboo of contact would protect the new-born and the mother. Women were not allowed to cook food for their husbands because doing so would adversely affect their hunting or impact their health in a manner similar to contact with menstruating women. My fieldwork also indicated that the time a woman and her new-born (and other children) spent with her kin strengthened relations between the children and their matrilateral kindred in a predominantly patrilocal system; after several births, a woman could rely on her natal kin for support. Over the last twenty years, first interethnic couples and later many Wampar have given up the post-partum taboo. Many interethnic couples found it difficult to find a place to stay or, in the case of the women, to travel to her place of origin. Young Wampar-Wampar couples then argued they would not have to obey the rule either and many men did not want their wives and children to leave the household. The emphasis on staying together as a nuclear family has become stronger and, in some cases, the bonding of children with their matrilateral kin weaker. Traditionally, the mother's brother had a very important position in the life of most Wampar, which tended to counterbalance the ideology of the patrilineage and the sagaseg.

Furthermore, school attendance of older children has made it more difficult to observe extended post-partum taboos. Gabsongkeg has an elementary school within the village and a primary school in walking distance. With the appearance of a new-born sibling, a child would either have to leave school to travel with the mother, or stay with the father or some other relative, a practical issue many would sooner avoid. Schooling has also had other implications for the rise of the nuclear family.

\subsection{Parenting and Education}

As noted, Wampar had no word that could easily be translated with 'family' (perhaps the use of mpan with its many related meanings ${ }^{10}$ gets closest to it). At Gabsongkeg 
elementary school, I took a picture of a signboard with word lists for language instruction in English and Tok Pisin: family/femili, father/papa, mother/mama, garden/gaden, baby/bebi. It is no coincidence that 'garden' follows 'father' and 'mother' on the list, as the garden is an intimate space shared by the couple and later the conjugal family, which sustains the household. The way that Wampar experience family life is translated and conceptualised in second and third languages for the children to learn (see also Figure 3).

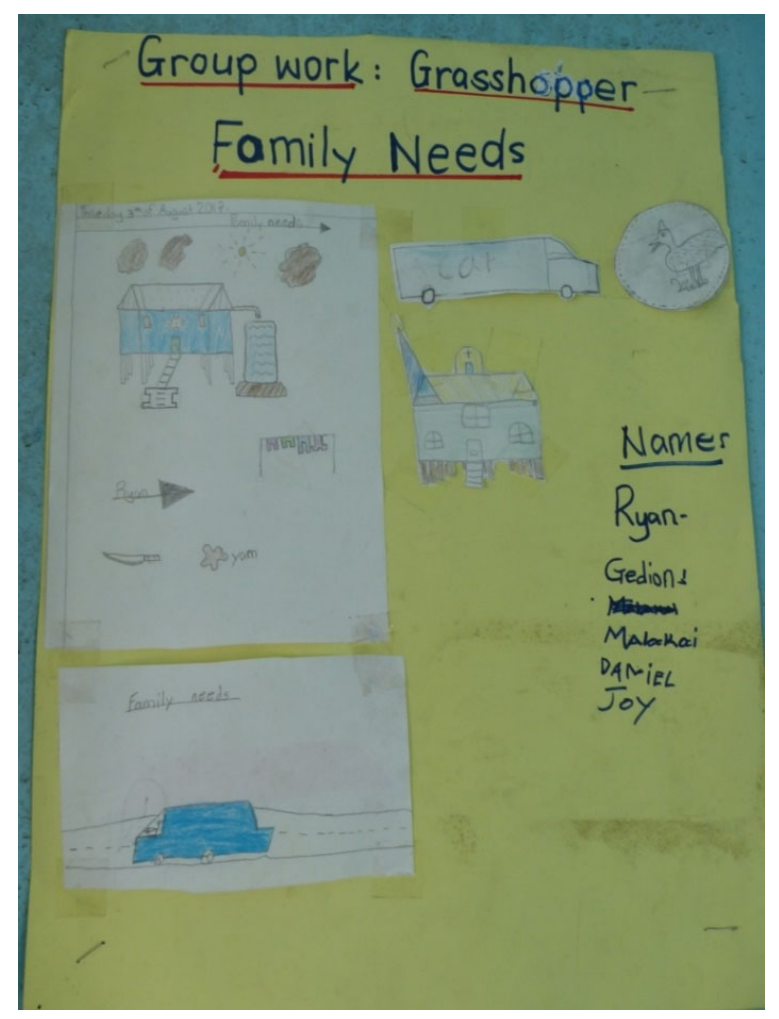

Figure 3. 'Family needs' results of a project at elementary school. The poster shows the family as a primary unit of production (bush knife to work in the garden and chicken to earn cash) and consumption (a house with a water tank and a car) (photo by the author).

When children are enrolled in school, they learn that they need not only a first name (in addition to a traditional and a nickname) ${ }^{11}$ but also a 'family name'. Usually, the father's name is used as family name, or in some cases the grandfather's name if he was an especially influential and prominent $\operatorname{man}^{12}$. Figure 4 shows a reproduction from a book on 'Government in Papua New Guinea' [74] for school children, edited by the Department of Education. It introduces ideas about the different 'units' of belonging by explaining a fictive address.

It is not too surprising that Ovia, the 'individual person' and citizen of Papua New Guinea, is male and that his primary social unit of belonging is a 'family group'. The whole presentation seems to accord with the idea and German expression of 'Familie als Keimzelle des Staates' (the family as the germ cell of the state). However, this does not support the idea of a 'western individual' opposed to a 'traditional Wampar dividual', for at the same time extra-familial kin ties are emphasised and reinforced in the state-promulgated vision of patrilineal clans as customary landowners. 


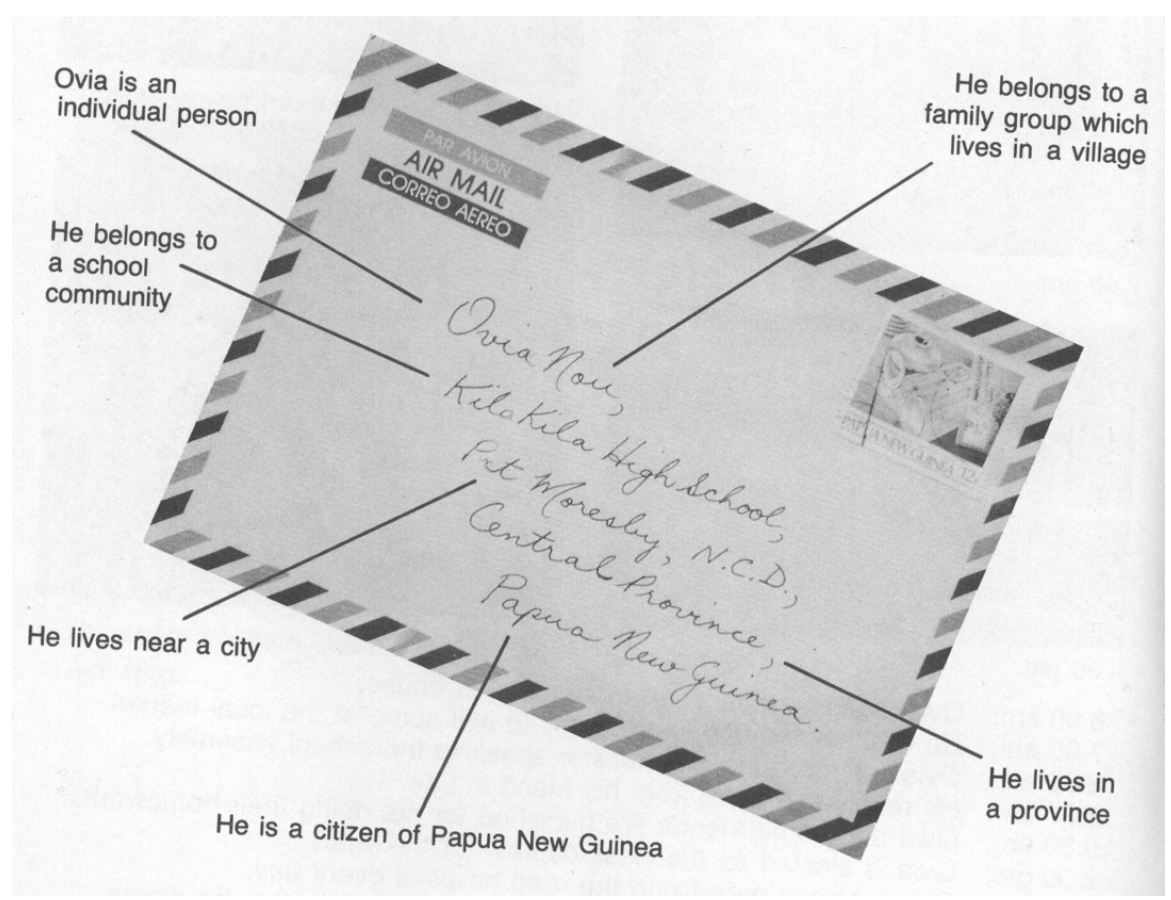

Figure 4. 'Ovia belongs to many groups' [74] (p. 2) (photo by the author).

Arland Thornton [32] has convincingly shown that the contemporary state's imperative of educating children outside the parental household has triggered many other changes to the domestic sphere and might be one of the areas where government policies have the biggest local impact, even in remote places. The choice of languages of instruction-invariably in a lingua franca or English-connects new words such as 'family' with the idea that it constituted by 'papa, mama, and bebi' (see above). In Papua New Guinea, the school's impact on the nuclear family is not limited to the teachings, incentives and punishments children experience at school, but also through the necessity to find school fees. School fees have been collected from colonial times, and they have remained important despite the Tuition Fee-Free (TFF) policy, introduced in 2012, because the overall funding required to maintain a school exceeds by a considerable margin what the central government provides. School fees have to be paid in cash and they are not part of the long-established system of mutual obligations that underpin bride-wealth payments or funeral expenses: they are an expense which must be shouldered largely by the parents, so that access to cash and a regular 'family-income' has become more essential to Wampar life. Parents make various attempts to generate income if they have no stable employment. I have, for example, attended a 'fund raising party' organized by a mother of many children trying to find school fees for one of her sons. However, another safety net is the system of namesakes of which Wampar children are still part. This involves a person-traditionally from the mother's side of the family - who agrees with the mother to pass on her or his name to the child [75,76] (p. 55). Namesakes have a special bond with a child: children visit them for extended periods (which also served to strengthen matrilateral ties), and if a child is sick or school fees have to be paid, then her or his namesake is expected to help [45] (pp. 156-157). Currently, namesakes are often chosen according to their capacity to help financially when needed ${ }^{13}$.

The education system and schooling might be the area where government policies have most directly implemented ideas of the family and changes in familial relations locally (cf. Thornton [32]). In the village government policies are noticeable in rules and regulations (for example school hours and fees) and in the curriculum as well as in the content of schoolbooks (e.g., Department of Education [74]). PNG, in the same manner as other nation states, proclaims in its constitution (1975 [77]) that 'the family unit be recognized as the fundamental basis of our society, and for every step to be taken to promote the moral, cultural, economic and social standing of the Melanesian family;' ... 
Interestingly 'family' is specified at the end of the sentence as 'Melanesian'. In the Family Protection Act [78], a very wide notion of the family is used: a person's family comprises spouses, children, parents, grandparents, as well as siblings of the person, or the person's spouse, and 'any other person who is treated by the spouse as a family member.' NGOs operating in PNG, however, are crucial to the provision of health (e.g., in the treatment of HIV or Aids and malaria), and in social welfare (child protection, gender discrimination, domestic violence, and so on) and work with understandings of 'family', proper family practices, and domesticity grounded in non-Melanesian lifeways.

These are only a few examples of the areas in which familification acts to mould local norms; others include the consumption of movies and television (conspicuously from the U.S., the Philippines or Nigeria), and advertising (through billboards, newspapers, T.V., and the internet) ${ }^{14}$. None of this is surprising, in that the family is an important site of capitalist consumption.

\section{Conclusions: Transformations of Sociality}

Wampar practices and understandings of kin relations call into question the helpfulness of oppositions (such as that between dividual and individual); binary questions, such as 'are the world's family systems converging or diverging?' [79], 'continuity or change [in the family]?'; and comments such as, 'The nuclear family is dead. Long live the family' [54]. Historically, and around the world, the problems of raising children and reproducing society have been solved in contrasting ways, often enough even within a particular region. In today's Markham Valley, we find different ethnicities, religious denominations and means of access to life's necessities. Wampar territories are differentially impacted by the proximity of the city of Lae, degree and timing of engagement with Christianity, and, today, by large-scale capitalist enterprises, all of which have effects on family life. Ideas imposed or borrowed jostle together with remembered or revitalised values and understandings ('patrilinearity', 'clan' and 'custom'), and inflect social relations, to a greater or lesser extent, emphasising some while downplaying others.

In the field of kin-based sociality, different transitions relevant to the emergence of the 'nuclear family' and revitalization of clans can be observed in Papua New Guinea, some of which seem to be in conflict with capitalism's imperatives, yet form part of the package it presents. Clans (sagaseg), traditionally taken as a fundamental unit, seemed to be declining in importance during an earlier phase of post-colonial history (when cashcrop production for local markets was significant), but they have gained an increased, if transformed, significance in the competition for income from land in the form of leases, rents and royalties as a result of government policies.

At the same time the Wampar family, now busy with raising school fees for their children, arranging the gendered division of labour (in cash-generating ventures no less than in producing basic garden foods), while aspiring to modern lifestyles and consumption patterns, and living up to ideals of companionate marriage and 'family life', has become much more important to the processes of social reproduction. Within these units, the patrilineal affiliation of the parents is often of so little relevance to the immediate concerns of young people that some are no longer aware of their sagaseg membership, even while ILG politics consume much of their parents' time.

Despite slower than expected economic growth, the link between dependence on resource income and conflict is apparent in PNG, as urbanization increases, an urban as well as the peri-urban middle class slowly evolves [13], and cash and Westernized consumption habits spread through the social fabric. In this context, the nuclear family has become an important social unit, where gender and generational discrepancies in the ability to supply wants and desires for material goods, education, and health care are negotiated; accordingly, tensions within families, between individual desires and household necessities, and between former ways of resolving conflicts and today's practices, become more apparent. Thus, in the process of emphasising the family, problems of domestic violence become more pressing. 
The nuclear family is a social entity seemingly beset by contradictions of capitalism rather than the source of Christian charity. Government and NGO activities, which try to solve problems of family and sexual violence by promoting family values, form part of the very process that fosters the troubles they aim to address. PNG is in this respect no exception: the nuclear family has never been the paradigm of peace and love that ideologies have portrayed, and anyway has not necessarily been the dominant or 'normal' family model [80] in Europe or other parts of the world.

Funding: This research was funded by Swiss National Science Foundation grant number 10001A_156039.

Informed Consent Statement: Informed consent was obtained from all interlocutors.

Data Availability Statement: The data is not publicly accessible.

Acknowledgments: I owe much to Don Gardner who discussed with me several versions of this article and to Jon Mathieu, with whom I co-taught a seminar on the emergence of the nuclear family, and who commented on earlier versions of this paper, as well as participants of the colloquia at the Departments of Ethnology in Hamburg and Munich. Doris Bacalzo, Willem Church, Lea Helfenstein and Tobias Schwoerer gave helpful feedback.

Conflicts of Interest: The author declares no conflict of interest.

\section{Notes}

For further ethnographic detail on the area and different Wampar villages, see [2,5,43-46,66,81-83].

2 'Die ehelichen Verhältnisse sind bei den Laewomba die denkbar traurigsten. Eine eheliche Liebe oder Zuneigung im christlichen Sinn kannte der Laewomba nicht. Die Frau, weil sie gekauft werden muss, ist ihm nur Handelsware, eine herzliche Zuneigung im christlichen Sinne kannte der Laewomba nicht. [ . . . ] Mann und Frau nehmen niemals die Mahlzeiten zusammen ein. [ ... ] Gehen Mann und Frau ins Feld, so geht die Frau immer einige Schritte hinter dem Manne her, sodass der Fremde den Eindruck haben würde, dass diese beiden gar nicht zusammengehören.'

3 The considerations presented here are part of a comparative longitudinal ethnography of international capital and local inequality among the Wampar in the Markham Valley. Our research aims to identify the micro-level interactions that constitute local, district and regional networks of sociality in three Wampar villages. Doris Bacalzo, Willem Church, Tobias Schwoerer and the author has been working as a team in this project, funded by the Swiss National Science Foundation (SNF). The arguments are based on fieldwork the author has conducted since 1997 (1999/2000, 2002, 2003/2004, 2009, 2013, 2016, 2017). These were funded by the German Research Foundation (DFG), Swiss National Science Foundation (SNF), and the University of Lucerne Research Committee (FoKo). The article is also based on published $[82,83]$ and unpublished manuscripts written by Hans Fischer.

4 In fact, the specifics of New Guinea societies led anthropologists to re-evaluate the models of descent as they had been applied in Africa too.

5 Strathern [51] characterised 'dividuality' as follows, 'Melanesian persons are as dividually as they are individually conceived. They contain a generalized sociality within. Indeed, persons are frequently constructed as the plural and composite site of the relationships that produced them. The singular person can be imagined as a social microcosm.' For a critique of these binary conceptions of Western and non-Western personhood and/or self, see Smith [84].

6 A critical appraisal of New Kinship Studies would be inappropriate here, and would exceed the space available. Such an appraisal, grounded in empirical research, is the subject of a forthcoming SNF-financed project entitled De-Kinning and ReKinning? Estrangement, Divorce, Adoption and the Transformation of Kin Networks. Our project investigates parent-child and affinal relations, and their ruptures, as forces fundamental to kinship networks.

7 Fischer [62] reports that until the 1970s, all Wampar conceptualized themselves as members of one of the roughly thirty named social units called sagaseg. Wampar today speak of sagaseg as patrilineal groups, but the incorporation of non-patrilineal kin remains common. Moreover, the fusion of non-related sagaseg and the fission of large sagaseg is historically verifiable.

8 In 2016, for the first time, while conducting census interviews, I met young Wampar who did not know to which sagaseg they belonged. This could be specific for the Gabsongkeg village and might have changed again with the importance of land claims and conflicts.

9 A women's dress introduced by the missions to cover naked breasts. It is also cut very wide to hide the shape of the body, somewhat in the manner of maternity clothing.

10 It ranges from group, family, household, lineage, to clan, descendants and 'tribe' or people.

11 On names, naming and social change, see $[44,45,62,75]$. 
First name and family names are listed for each class, the production of lists is one of the colonial techniques which has been taken over and is used for all kinds of occasions with great diligence. In addition, this occurs in more traditional areas, as for example the collection of contributions to bride prices (see Anthony Pickles on listing bridewealth contributions [85]). In the case of girls-as in former times-the namesakes will receive according to their contribution a share or even the full bridewealth paid sometime after marriage of her or his namesake.

The Bank of the South Pacific, for example, ran a 2015 promotion in which a young man who had won 20000 kina and was quoted that his win had changed his life because he now had a basis for hoping his wish to build a 'family home' might come true.

\section{References}

1. Anderson, T. Land and Livelihoods in Papua New Guinea; Scholarly Publishing: Melbourne: Australian, 2015.

2. Beer, B. Gender and inequality in a postcolonial context of large-scale capitalist projects in the Markham Valley, Papua New Guinea. Aust. J. Anthropol. 2018, 29, 348-364. [CrossRef]

3. Fischer, H.; Beer, B. Wampar_English Dictionary with an English—Wampar Finder List; ANU Press: Canberra, Australia, 2021.

4. Mathieu, J. House, Family, Kinship: Domestic Terminologies: House, household, family. In Historical Handbook of the Domestic Sphere in Europe; Eibach, J., Lanzinger, M., Eds.; Routledge: London, UK, 2020; pp. 25-42.

5. Fischer, H. (Ed.) Wampar: Berichte über die Alte Kultur Eines Stammes in Papua New Guinea; Übersee-Museum Bremen: Bremen, Germany, 1978.

6. Hrdy, S.B. Mother Nature. In Maternal Instincts and How They Shape the Human Species; Ballantine Books: New York, NY, USA, 2000.

7. Cole, J.; Thomas, L.M. (Eds.) Love in Africa; University of Chicago Press: Chicago, IL, USA, 2009.

8. Hirsch, J.S.; Wardlow, H. (Eds.) Modern Loves. In The Anthropology of Romantic Courtship \& Companionate Marriage; University of Michigan Press: Ann Arbor, MI, USA, 2006.

9. Heiman, R.; Freeman, C.; Liechty, M. (Eds.) The Global Middle Classes: Theorizing through Ethnography; Sar Press: Santa Fe, NM, USA, 2012.

10. Kroeker, L.; O'Kane, D.; Scharrer, T. (Eds.) Middles Classes in Africa: Changing Lives and Conceptual Challenges; Palgrave Macmillan: Cham, Switzerland, 2018.

11. Lentz, C. African middle classes: Lessons from transnational studies and a research agenda. In The Rise of Africa's Middle Class; Melber, H., Ed.; Zed Books: London, UK, 2016; pp. 17-53.

12. Rosi, P.; Zimmer-Tamakoshi, L. Love and Marriage Among the Educated Elite in Port Moresby. In The Business of Marriage: Transformations in Oceanic Matrimony; Marksbury, R., Ed.; University of Pittsburgh Press: Pittsburgh, PA, USA; London, UK, 1993; pp. 157-174.

13. King, M. Elites, Suburban Commuters and Squatters. The Emerging Urban Morphology of Papua New Guinea. In Modern Papua New Guinea; Zimmer-Tamakoshi, L., Ed.; Thomas Jefferson University Press: Kirksville, MO, USA, 1998; pp. $183-194$.

14. Cox, J. 'Grassroots', 'Elites' and the New 'Working Class' of Papua New Guinea. In Brief; State, Society \& Governance in Melanesia; Australian National University: Canberra, Australia, 2014; Volume 6.

15. Cox, J. Fast Money Schemes Hope and Deception in Papua New Guinea; Indiana University Press: Bloomington, IN, USA, 2018.

16. Cox, J.; Macintyre, M. Christian Marriage, Money Scams, and Melanesian Social Imaginaries. Oceania 2014, 84, 138-157. [CrossRef]

17. Gewertz, D.; Errington, F.K. Emerging Class in Papua New Guinea: The Telling of a Difference; Cambridge University Press: Cambridge, $\mathrm{UK}, 1999$.

18. Gewertz, D. Retelling Chambri Lives: Ontological Bricolage. Contemp. Pac. 2016, 28, 347-381. [CrossRef]

19. Coe, C. What is the impact of transnational migration on family life? Women's comparisons of internal and international migration in a small town in Ghana. Am. Ethnol. 2011, 38, 148-163. [CrossRef]

20. Coe, C. The Scattered Family: Parenting, African Migrants, and Global Inequality; The University of Chicago Press: Chicago, IL, USA, 2014.

21. Parreñas, R.S. Long distance intimacy: Class, gender, and intergenerational relations between mothers and children in Filipino transnational families. Glob. Netw. 2005, 5, 317-336. [CrossRef]

22. Parreñas, R.S. Children of Global Migration: Transnational Families and Gendered Woes; Stanford University Press: Stanford, CA, USA, 2005.

23. Drotbohm, H. Horizons of long-distance intimacies: Reciprocity, contribution and disjuncture in Cape Verde. Hist. Fam. 2009, 14, 132-149. [CrossRef]

24. Drotbohm, H. Familie als zentrale Berechtigungskategorie der Migration: Von der Transnationalisierung der Sorge zur Verrechtlichung sozialer Bindungen [Family as a category of entitlement for migration: From the transnationalisation of the concern to the juridification of social bonds]. In Kultur, Gesellschaft, Migration: Die Reflexive Wende in der Migrationsforschung [Culture, Society, Migration: The Reflexive Turn in the Studies of Migration]; Nieswand, B., Drotbohm, H., Eds.; VS Springer: Wiesbaden, Germany, 2014.

25. Alber, E.; Notermans, C.; Martin, J. (Eds.) Child Fostering in West Africa; New Perspectives on Theory and Practices; Brill: Leiden, The Netherlands, 2013.

26. Archambault, C. Fixing families of mobile children: Recreating kinship and belonging among Maasai adoptees in Kenya. Childhood 2010, 17, 229-242. [CrossRef] 
27. Leinaweaver, J.B. The Circulation of Children: Kinship, Adoption, and Morality in Andean Peru; Duke University Press: Durham, UK, 2008.

28. Leinaweaver, J.B.; Marre, D.; Frekko, S.E. 'Homework' and Transnational Adoption Screening in Spain: The Co-Production of Home and Family. J. R. Anthropol. Inst. 2017, 23, 562-579. [CrossRef]

29. Miller, D. The Dialectics of Shopping; University of Chicago Press: Chicago, IL, USA, 2001.

30. Miller, D. What is a Relationship? Is Kinship Negotiated Experience? Ethnos 2007, 72, 535-554. [CrossRef]

31. Bales, R.F.; Parsons, T. Family, Socialization, and Interaction Process; Routledge: London, UK, 1956.

32. Thornton, A. Reading History Sideways: The Fallacy and Enduring Impact of the Developmental Paradigm on Family Life; The University of Chicago Press: Chicago, IL, USA, 2005.

33. Jayakody, R.; Thornton, A.; Axinn, W. (Eds.) International Family Change: Ideational Perspectives; Lawrence Erlbaum Associates: New York, NY, USA; London, UK, 2008.

34. Morgan, D. Family Connections: An Introduction to Family Studies; Polity Press: Cambridge, UK, 1996.

35. Morgan, D. Acquaintances: The Space between Intimates and Strangers; Open University Press: New York, NY, USA, 2009.

36. Morgan, D. Rethinking Family Practices; Palgrave Macmillan: Basingstoke, UK, 2011.

37. Widmer, E.D. Family configurations. A Structural Approach to Family Diversity; Routledge: London, UK, 2016.

38. Nave-Herz, R. Familie Heute: Wandel der Familienstrukturen und Folgen für die Erziehung [Family Today: Change of the Family Structures and Consequences for the Education]; Primus Verlag: Darmstadt: Germany, 2015.

39. Jamieson, L. Intimacy: Personal Relationships in Modern Societies; Polity Press: Cambridge, UK, 1998.

40. Jamieson, L. Intimacy Transformed? A Critical Look at the 'Pure Relationship'. Sociology 1999, 33, 477-494.

41. Jamieson, L. Intimacy as a Concept: Explaining Social Change in the Context of Globalisation or Another Form of Ethnocentricism? Sociol. Res. Online 2011, 16, 151-163. [CrossRef]

42. Barnes, J.A. African Models in the New Guinea Highlands. Man 1962, 62, 5-9. [CrossRef]

43. Bacalzo, D.; Beer, B.; Schwoerer, T. Mining narratives, the revival of «clans» and other changes in Wampar social imaginaries: A case study from Papua New Guinea. Journal de la Société des Océanistes 2014, 138-139, 63-76. [CrossRef]

44. Bacalzo Schwoerer, D. Transformations in kinship, land rights and social boundaries among the Wampar in Papua New Guinea and the generative agency of children of interethnic marriages. Childhood 2012, 19, 332-345. [CrossRef]

45. Bacalzo Schwoerer, D. Processes of becoming: Transcultural socialization and childhood among the Wampar. Tsantsa 2011, 16, 154-158.

46. Beer, B.; Schroedter, J.H. Social Reproduction and Ethnic Boundaries: Marriage Patterns through Time and Space Among the Wampar, Papua New Guinea. Sociologus 2014, 64, 1-28. [CrossRef]

47. Zimmer-Tamakoshi, L. Development and Ancestral Gerrymandering: Schneider in Papua New Guinea. In The Cultural Analysis of Kinship: The Legacy of David M. Schneider (187-203); Feinberg, R., Ottenheimer, M., Eds.; University of Illinois Press: Urbana, IL, USA, 2001.

48. Schneider, D. A Critique of the Study of Kinship; University of Michigan Press: Ann Arbor, MI, USA, 1984.

49. Strathern, M. Kinship, Law and the Unexpected. Relatives Are Always a Surprise; Cambridge University Press: Cambridge, UK, 2005.

50. Carsten, J. After Kinship; Cambridge University Press: Cambridge, UK, 2004.

51. Strathern, M. The Gender of the Gift; University of California Press: Berkeley, CA, USA, 1988; Volume 6.

52. McKinnon, S. On Kinship and Marriage: A Critique of the Genetic and Gender Calculus of Evolutionary Psychology. In Complexities Beyond Nature E Nurture; McKinnon, S., Silverman, S., Eds.; University of Chicage Presss: Chicago, IL, USA; London, UK, 2005; pp. 106-131.

53. Weismantel, M. Making Kin: Kinship Theory and Zumbagua Adoptions. Am. Ethnol. 1995, 22, 685-704. [CrossRef]

54. Godelier, M. The Metamorphosis of Kinship; Verso: London, UK, 2011.

55. Weiner, J.F. The Incorporated What Group: Ethnographic, Economic and Ideological Perspectives on Customary Land Ownership in Contemporary Papua New Guinea. Anthropol. Forum 2013, 23, 94-106. [CrossRef]

56. Independent State of Papua New Guinea. Land Registration (Amendment) Act; Independent State of Papua New Guinea: Port Moresby, Papua New Guinea, 2009.

57. Macintyre, M. The Persistence of Inequality. Women in Papua New Guinea since Independence. In Modern Papua New Guinea; Zimmer-Tamakoshi, L., Ed.; Thomas Jefferson University Press: Kirksville, MO, USA, 1998; pp. 211-228.

58. Filer, C.; Le Meur, P.-Y. (Eds.) Large-Scale Mines and Local-Level Politics between New Caledonia and Papua New Guinea; Australian National University Press: Canberra, Australian, 2017; Volume 12.

59. Minnegal, M.; Lefort, S.; Dwyer, P.D. Reshaping the Social: A Comparison of Fasu and Kubo-Febi approaches to Incorporating Land Groups. Asia Pac. J. Anthropol. 2015, 16, 496-513. [CrossRef]

60. Mowbray, J. 'Ol Meri Bilong Wok' (Hard-working women): Women, work and domesticity in Papua New Guinea. In Divine Domesticities: Christian Paradoxes in Asia and the Pacific; Choi, H., Jolly, M., Eds.; ANU Press: Canberra, Australia, 2014; pp. 167-197.

61. McDonnell, S.; Allen, M.; Filer, C. (Eds.) Kastom, Property and Ideology: Land Transformations in Melanesia; Australian National University Press: Canberra, Australia, 2017.

62. Fischer, H. Gabsongkeg '71: Verwandtschaft, Siedlung und Landbesitz in Einem Dorf in Neuguinea [Gabsongkeg '71: Kinship, Settlement and Land Ownership in a Village in New Guinea]; Klaus Renner: München, Germany, 1975. 
63. Bainton, N. Keeping the Network out of view: Mining, Distinctions and Exclusion in Melanesia. Oceania 2009, 79, 18-33. [CrossRef]

64. Gilberthorpe, E. Community development in Ok Tedi, Papua New Guinea: The role of anthropology in the extractive industries. Community Dev. J. 2013, 48, 466-483. [CrossRef]

65. Guddemi, P. Continuities, Contexts, Complexities, and Transformations: Local Land Concepts of a Sepik People Affected by Mining Exploration. Anthropol. Forum 1997, 7, 629-648. [CrossRef]

66. Schwoerer, T. (Forthcoming). Plantations, Incorporated Land Groups, and Emerging Inequalities among the Wampar of Papua New Guinea. In Capital and Inequality in Rural Papua New Guinea; Asia-Pacific Environment, Monographs; Beer, B., Schwoerer, T., Eds.; ANU Press: Canberra, Australia, 2022.

67. Fischer, H. Randfiguren der Ethnologie. Gelehrte und Amateure, Schwindler und Phantasten [Marginal Actors in Ethnology. Scholars and Amateurs, Impostors and Dreamer ]; Kapitel 6: Der Missionar (Chapter 6: The missionary); Reimer: Berlin, Germany, 2003.

68. Spellenberg, H. Er Führte Mich auf Rechter Straße: Ein Stück Lebensweg von Neuguinea nach Württemberg 1917-1948 [He Led Me on the Right Road: A Piece of the Path of Life from New Guinea to Württemberg 1917-1948]; Eigenverlag: Reutlingen, Germany, 2001.

69. Langmore, D. The object lesson of a civilised, Christian home. In Family and Gender in the Pacific: Domestic Contradictions and the Colonial Impact; Jolly, M., Macintyre, M., Eds.; Cambridge University Press: Cambridge, UK, 1989; pp. 84-94.

70. Jolly, M.; Macintyre, M. Macintyre Introduction. In Family and Gender in the Pacific: Domestic Contradictions and the Colonial Impact; Jolly, M., Macintyre, M., Eds.; Cambridge University Press: Cambridge, UK, 1989; pp. 1-18.

71. Wardlow, H. All's fair when love is war. Romantic passion \& companionate marriage among the Huli of Papua New Guinea. In Modern Loves: The Anthropology of Romantic Courtship and Companionate Marriage; Hirsch, J.S., Wardlow, H., Eds.; University of Michigan Press: Ann Arbor, MI, USA, 2006; pp. 51-77.

72. Wardlow, H. The Task of the HIV Translator: Transforming Global AIDS Knowledge in an Awareness Workshop. Med. Anthropol. 2012, 31, 404-419. [CrossRef] [PubMed]

73. Wardlow, H. Paradoxical Intimacies: The Christian Creation of the Huli Domestic Sphere. In Divine Domesticities: Christian Paradoxes in Asia and the Pacific; Choi, H., Jolly, M., Eds.; ANU Press: Canberra, Australia, 2014; pp. 325-345.

74. Department of Education, Government in Papua New Guinea. Social Science Pupil Book; Department of Education: Port Moresby, Papua New Guinea, 1987.

75. Fischer, H. Namen als ethnographische Daten [Names as ethnographic data]. In Abhandlungen und Berichte des Staatlichen Museums für Völkerkunde Dresden; Akademie-Verlag: Berlin, Germany, 1975; Volume 34, pp. 629-654.

76. Fischer, H. Wörter und Wandel: Ethnographische Zugänge über die Sprache [Words and Change: Ethnographic Approaches through Language]; Reimer: Berlin, Germany, 2000.

77. Independent State of Papua New Guinea. Constitution of the Independent State of Papua New Guinea; Independent State of Papua New Guinea: Port Moresby, Papua New Guinea, 1975.

78. Independent State of Papua New Guinea. Familiy Protection Act 2013; Independent State of Papua New Guinea: Port Moresby, Papua New Guinea, 2013.

79. Therborn, G. Family Systems of the World: Are They Converging? In The Wiley Blackwell Companion on the Sociology of Families; Treas, J., Scott, J., Richards, M., Eds.; Wiley Blackwell: Hoboken, NJ, USA, 2014; pp. 3-19.

80. Canetto, S. What is a normal family? Common assumptions and current evidence. J. Prim. Prev. 1996, 17, 31-46. [CrossRef] [PubMed]

81. Beer, B.; Church, W. Roads to Inequality: Infrastructure and Historically Grown Regional Differences in the Markham Valley, Papua New Guinea. Oceania 2019, 89, 2-19. [CrossRef]

82. Fischer, H. Weisse und Wilde: Erste Kontakte und Anfänge der Mission [Whites and Savages: First Contacts and the Beginning of the Mission]; Reimer: Berlin, Germany, 1992.

83. Fischer, H. Geister und Menschen: Mythen, Märchen und neue Geschichten [Ghosts and Humans: Myths and New Stories]; Reimer: Berlin, Germany, 1994.

84. Smith, K. From dividual and individual selves to porous subjects. Aust. J. Anthropol. 2012, 23, 50-64. [CrossRef]

85. Pickles, A. To Excel at bridewealth, or ceremonies of Office. Anthropol. Today 2017, 33, 19-22. [CrossRef] 